\title{
Entrepreneurial Performance: The Role of Literacy and Skills
}

\author{
Tuty SARIWULAN ${ }^{1}$, Suparno SUPARNO², Disman DISMAN ${ }^{3}$, Eeng AHMAN ${ }^{4}$, Suwatno SUWATNO ${ }^{5}$
}

Received: August 01, 2020 Revised: September 28, 2020 Accepted: October 05, 2020

\begin{abstract}
This research aims to determine the direct and indirect effects of digital literacy, economic literacy, and entrepreneurial skills on the performance of small- and medium-sized enterprises (SMEs) in garment clusters in the Bulak tourism industry Depok. Carrying out quantitative research with survey methods, data collection is using a questionnaire technique with 90 respondents, via saturation sampling. This research data analysis uses SPSS software version 25.0. Path analysis is used to determine the direct and indirect effects between variables. The results showed digital literacy, economic literacy, and entrepreneurial skills significantly and positively affect the performance of small- and medium-sized enterprises. The main finding in this study is that digital literacy has the greatest influence on the performance of SME entrepreneurs, both directly and indirectly. The results of the study provide input on performance development strategies for SME entrepreneurs through digital literacy, including digital business relationships, online facilities, and networks. The findings are also complementary to the factors shaping the performance of SME entrepreneurs in the digital age. The research results show that digital literacy has the greatest direct and indirect influence on the performance of SME entrepreneurs; this shows the essential contribution of digital literacy in developing business and marketing networks.
\end{abstract}

Keywords: Performance of SMEs, Entrepreneurial skills, Digital literacy, Economic Literacy, Shopping Tourism

JEL Classification Code: L25, L26, D83, I25, L83

\section{Introduction}

The development of small- and medium-sized enterprises has become the focus of studies for entrepreneurship researchers. How does business survive in times of crisis (Bourletidis \& Triantafyllopoulos, 2014), in particular with the COVID 19 pandemic (Kuckertz et al., 2020; Maritz

${ }^{1}$ First Author. Associate Professor, Faculty of Economics, Universitas Negeri Jakarta, Indonesia. Email: tuty.wulan@unj.ac.id

${ }^{2}$ Corresponding Author. Lecturer, Faculty of Economics, Universitas Negeri Jakarta, Indonesia [Postal Address: Gd. R,

Faculty of Economics, Universitas Negeri Jakarta. Campus A, Jl. Rawamangun Muka, East Jakarta, DKI Jakarta, 13220, Indonesia] Email: Suparno@feunj.ac.id

${ }^{3}$ Professor, Faculty of Economics and Business, Universitas pendidikan Indonesia, Indonesia. Email: disman@upi.edu

${ }^{4}$ Professor, Faculty of Economics and Business, Universitas pendidikan Indonesia, Indonesia. Email: eengahman@upi.edu

${ }^{5}$ Professor, Faculty of Economics and Business, Universitas pendidikan Indonesia, Indonesia. Email: suwatno@upi.edu

() Copyright: The Author(s)

This is an Open Access article distributed under the terms of the Creative Commons Attribution Non-Commercial License (https://creativecommons.org/licenses/by-nc/4.0/) which permits unrestricted non-commercial use, distribution, and reproduction in any medium, provided the original work is properly cited. et al., 2020), and can grow its business in the digital age so that it needs strategy and business innovation (Satalkina, 2020; Wu, 2019). In the human resources economy, the skills of an entrepreneur can be learned, educated, and developed (Sharma, 2016). Such competencies are important because entrepreneurship is for a unique person an ability to take advantage of opportunities and courage to take risks. The condition makes not all starters of the business a success

Entrepreneurship as a buffer of the national economy has become a program of world economic development (Savrul, 2017; Valliere \& Peterson, 2009). The study of entrepreneurship is an important issue in achieving social welfare from how to do business, what its competence, and how to manage a business in today's digital age to prosperity. The government's economic system is an important part of encouraging the development of entrepreneurship, especially for the younger generation who wants to compete internationally. It requires the right policies on the management on the part of entrepreneurs, especially social entrepreneurs. Social entrepreneurs are people who have innovation and creativity potential to solve problems in society.

Entrepreneurship is studied in college through economic education and entrepreneurial practice, but ultimately it is 
the skills (Suparno \& Saptono, 2018) of every entrepreneur to be able to open and develop entrepreneurship. The experience of economic learning obtained is sufficient at the University of Economics in Indonesia where the average student takes entrepreneurship courses, introduction to economics, business, accounting, and finance, as well as management. But the entrepreneur's training needs to be reviewed to assess whether the economic and financial literacy that has been obtained affects the development of its business. Entrepreneurship and business confidence are studied in anticipation of unemployment and entrepreneurial intentions for the younger generation. Camba (2020) states that there is a relationship between entrepreneurship and business confidence in the long term, while in the short term unemployment decreases with an increase in entrepreneurship and business confidence.

Various digital businesses are growing rapidly in the world including in Indonesia (Tayibnapis et al., 2018). Digital entrepreneurship by the young generation is growing startups so it needs to be studied (Reis et al., 2018). For example, in Indonesia, elementary school age children dream of being YouTubers, become a public figure and be successful in digital business. They have known digital business through social media, which is triggered by the environment and the demands of a difficult life. High school level learning has assigned students the task of learning to make simple products or marketing through the "online market" web. Such progress is better than previous generations studying e-commerce at the university level. The existence of digital business transformation in e-commerce needs to be learned (Saptono et al., 2020) and anticipated as a business organizational capability (Nadeem et al., 2018), including the ability of entrepreneurs in business development, because education affects the skills and ability to manage the business (Suparno et al., 2019; Nurjanah et al., 2020).

Bulak tourism industry Depok City is a business place that has been engaged in garment confection since 1980 . At first glance, the location of this center is in a narrow road, like a village. But this small industrial center becomes a wholesale place for big traders and tourism shopping. While supermarkets are closing, this tourist village is still able to grow. Cheap price, good quality, models that follows fashion are the choice for the buyers. If schools provide entrepreneurship learning in producing goods and services, this tourism village indirectly becomes an entrepreneurial learning center for the community in the production and marketing process that is integrated with the regions. This is a rare state of affairs, because it requires mutual respect, cooperation and social responsibility; not just focusing on business competition, but on how to progress and prosper together.

The state needs entrepreneurship to continue to be developed to drive the economy of a country (Quatraro
\& Vivarelli, 2013; Egedy et al., 2018), to encourage the production of goods and services (Hunt \& Kiefer, 2017), driving the flow of demand and money turnover as well as the driving force and driver engine of the economy in a country (Raposo \& do Paço, 2011). Whereas the economy emphasizes capital intensive and big business, entrepreneurship emphasizes labor intensive and interest on small loans. There is the political will from the government to grow and prosper society. Entrepreneurship is the basis of the economy, which requires special attention. The contribution of entrepreneurs in innovation and productivity provides economic change and renewal (Ambad \& Damit, 2016; Heinonen \& Poikkijoki, 2006), reducing unemployment by creating jobs for the community, and sustain economic growth (Van Gelderen et al., 2008).

Garment clusters in the Bulak tourism industry Depok City can develop and survive in the era of the digital entrepreneurial industry. Cluster-based entrepreneurial development is very important to review and develop (Suparno et al., 2019). A unique industrial village with tourism village-based marketing, where most of the population is craftsmen and in confection. The advantage of this location is that many traders from large markets buy and order from entrepreneurs. Traders came from big markets as are tourists. They can reach the ASEAN region through traders from the "Tanah Abang" market as well as online. The uniqueness of the location of the entrepreneurial village needs to be researched as regards the development of its business so that it can become a model in the development of local entrepreneurial-based businesses globally. Unemployment goes from the village to the city, but residents from the city to the tourist village will acquire new skills as entrepreneurs.

It is necessary to identify business development for tourist villages amid the challenges of the modern world today. The performance of SMEs to be able to open new businesses and achieve sales targets relies on digital literacy using social media and online commerce conducted by entrepreneurs; they also rely on economic literacy as an educational experience through both formal school and economic experience in public life; and entrepreneurs are to learn working skills to manage their business well.

\section{Literature Review}

\subsection{Performance of SME entrepreneurs}

The development of SME business as an entrepreneurial endeavor is very closely related to the performance of entrepreneurs. Entrepreneurs as managers run business organizations by implementing production management, resource capacity, financial governance, with the courage to take opportunities and risks, and marketing. The ability to achieve business targets based on potential and resource 
ownership becomes a challenge for every entrepreneur's performance. This will be related to efficiency and effectiveness.

Van Vuuren (Sebikari, 2014) stated that entrepreneurial performance is the ability to achieve established entrepreneurial goals. Further conveying that performance as an ability utilizes the available business opportunities to increase the effort. Performance is related to achieving work based on business targets by leveraging available opportunities. These conditions contain measurable risks that an entrepreneur should analyze and anticipate. Several factors are determined in preparing for entrepreneurship. Entrepreneurial attitudes and intentions can be explained by several factors such as need for achievement, risk perception, and locus of control (Wardana et al., 2020).

Kaplan and Norton (Looy \& Shafagatova, 2016) state that the four dimensions in an organization's performance are financial perspectives, customer perspective, business process perspectives, and "learn and grow" perspectives. Based on this view, performance is very closely related to business development targets to be able to grow and take advantage of opportunities and conditions both financial, customer, and production capacity. In entrepreneurship with an SME focus, the improvement in the performance of entrepreneurs is seen from the increasing production capacity and the achievement of the number of sales in generating total production and the total profit that can be achieved.

The performance of entrepreneurs is also related to the efficient and effective management of resources. This will be very influential in achieving business results with proper management of production capacity. Entrepreneurial performance (Sebikari, 2014) is measured by return on investment, market share, profitability, and sales growth. This indicates that the performance is very close to the achievement and improvement of business in production, sales, and profit.

Based on the above review of the performance of SME entrepreneurs is the ability to manage their resources according to the objective stipulated. In this study, the performance of SME entrepreneurs was measured by the ability to increase production, business unit development, increase in the volume of sales, and business profits.

\subsection{Entrepreneurial skills}

Entrepreneurial skills begin with innovation sparked by personal factors and environmental factors. Personal factors that influence entrepreneurship are education, experience, commitment, vision, the courage to take risks, and age. While environmental factors are sociology, organization, family, opportunity, competitors, investors, and government policy. Entrepreneurial skills can be learned and developed (Suparno \& Saptono, 2018). Entrepreneurship for the younger generation can be grown through entrepreneurship education that fosters entrepreneurial intentions. Perceived desirability is the most influential factor in fostering entrepreneurial intentions by starting a business (Bui et al., 2020)

Skills in entrepreneurship demonstrate an ability to create something new and different. Innovation and creativity as capital in cooperation and competition. The rapid development of the business, demands different skills. Many opportunities can be utilized with innovation and creativity. Such skills need to be developed including technical and managerial capabilities, including taking risky business decisions. This is important to introduce and learn in entrepreneurial intentions as real skills and efforts build a business. Entrepreneurial intentions were introduced in the theory of planed behavior (Ajzen, 2005), which explains that attitudes, personality and behavior form entrepreneurial intentions. This indicates that the intention is very important as a real step to start entrepreneurship. Developing concepts and studies based on these theories ( $\mathrm{Lu}$ $\&$ Wang, 2018) found the dimension of alertness as a major factor in entrepreneurship. We need to develop this study in the analysis of entrepreneurial performance in skills and knowledge as the main basis for entrepreneurial competence.

Entrepreneurial skills (Fitriati \& Hermiati, 2011) consist of technical skills as an ability to manage business operations; management skills include planning and organizing, identifying customers and channels in attribution, managing resources; personal maturity skills are skills in self-awareness, business reflection, problem-solving and finding solutions. The study of entrepreneurial skills (Suparno \& Saptono, 2018) consist of 1) technical communication, environment monitoring, problem-solving, technology implementation and use, interpersonal, and organizational skills; 2) business management planning and goal setting, decisionmaking, human resources management, marketing, finance, accounting, customer relations, quality control, negotiation, business launch, growth management, and compliance with regulations skills; 3) personal entrepreneurial self-control and discipline, risk management, innovation, persistence, leadership, change management, network building, and strategic thinking.

In this study, entrepreneurial skills are the ability possessed by an SME entrepreneur in developing his business, covering technical skills, management skills, entrepreneur skills, and personal maturity skills, which is reflected in the measurement results in the form of scores obtained through respondents' answers from a set of questions using the assessment scale given to SME entrepreneurs.

\subsection{Economic literacy}

Rapid economic development demands the ability to carefully anticipate economic conditions. That is economic 
knowledge in an learning experience both formally and nonformally. Socioeconomic life in society is good economic learning because economic conditions teach individuals how can build businesses, develop, avoid crises, even take risks to be able to achieve business expansion. In general, it is part of economic literacy, which consists of economic and financial knowledge.

Literacy also contains a good understanding of basic economic problems, to solve economic problems with the right decisions. Good literacy should also be possessed by entrepreneurs because they must master manufacturer's behavior, consumer behavior, and limited resource optimization require priority scale. Consumer behavior is an analysis and basis for developing production for entrepreneurs. On the other hand, producer behavior is part of consumer decisions. Today, we find a lot of training on "being smart to be a consumer", managing income, prospering in old age, managing intake and preparing for the future. This is the risk bearing of economic knowledge as literacy helped towards smart choices to live a prosperous life in the future.

Economic literacy is not only obtained through formal education, non-formal education in public life, as well as the information received from various sources personally. It can also provide more knowledge and improve economic literacy with basic assistance that has been received via informal education. Daily economic life forges entrepreneurial knowhow to be rational in optimizing the economy towards prosperity. We often find consumers making decisions; income expenditure is based on wants and needs, but economic behavior changes when there are many discounts for other items that are not the priority scale. Economic literacy plays an important role here, because basically rationality is the basis for making economic decisions. Economic wants without purchasing power can lead to debt.

In "Entrepreneurship education and its influence on financial literacy and entrepreneurship skills in college", Suparno (2018) states that financial literacy greatly affects how students acquire entrepreneurial skills. This indicates that, if financial literacy is developed in higher education, it will provide sufficient literacy as an entrepreneur's provision. Financial literacy is a much-needed knowledge in recent policy debates given that it involves an understanding of debt, investment, and spending patterns (Lusardi \& Mitchell, 2007).

Economic literacy according to NCEE (The National Center on Education and the Economy) developed 20 indicators measuring people's economic literacy levels (Iqomudin, 2017). In economic literacy, research is adjusted with indicators to measure the literacy of SME entrepreneurs as the ability to analyze changes in demand for goods, manage the role of entrepreneurship, analyze market changes, analyze the impact of government policy, use resources, analyze the costs and benefits of economic transactions, analyze the impact of inflation, and analyze business development.

\subsection{Digital literacy}

The development of technology and information has brought the current generation into the world of digital literacy. In 2016, a total of 132.7 million Indonesians were connected to the Internet, out of 256.2 million. The utilization of e-commerce by SMEs is part of digital literacy. The constraints of SMEs to use e-commerce include, among others, lack of technical understanding of information technology, the high cost of Internet access only accessible to some people, complaints from buyers because the goods do not match the original and some other constraints (Candra \& Ashari, 2014).

Entrepreneurship is also the emergence of a new elite group, who want to get respect and income in society as a social status. Business uncertainty creates speculation and trust as opportunities. Looking to the future of business opportunities requires intuitive skills, which is an important strategy for entrepreneurs (Aujirapongpan et al., 2020) with the challenges of the very rapid and rapid development of the business world in the field of information and technology.

Digital literacy is the ability of entrepreneurs to adapt to the development of the technology world to be able to utilize media as communication, marketing, analyzing trends, and demand for goods and services. Social media is a very important part today as people are always in touch with smartphones. Various applications make it very easy to manage businesses and expand the reach of the online market. Various groups, trending topics, and communities are very important for business entrepreneurs to follow. Such capabilities, developed with web management into e-commerce, supported by big data and coding, are conditions to launch a start-up where technology-based entrepreneurs can communicate and reach the wider market.

Technology can also increase corporate entrepreneurship, with indications of organizational innovation, self-renewal, new business discovery, and responsiveness (Alvarez \& Barney, 2007). With technology, SMEs can increase the level of accuracy in innovating, which can ultimately increase the added value of the company. Gilster (Lankshear \& Knobel, 2015) states that digital literacy is defined as the ability to understand and use information in various forms from a wide range of sources accessed through computer devices. In detail, digital literacy consists of the ability to access, manage, integrate, analyze, and evaluate information, build new knowledge, and create and communicate with others to participate effectively. Based on the above review, the following hypotheses are formulated:

H1: Digital literacy is significantly and positively related to performance of SME entrepreneurs 
H2: Digital literacy is significantly and positively related to entrepreneurial skills

H3: Economic literacy is significantly and positively related to entrepreneurial skills

H4: Economic literacy is significantly and positively related to performance of SME entrepreneurs

H5: Entrepreneurial skills are significantly and positively related to performance of SME entrepreneurs

\section{Research Methods and Materials}

This research is a quantitative study, which aims to determine the direct and indirect effects of digital literacy, economic literacy, and entrepreneurial skills on the performance of SME entrepreneurs. Data were collected by survey with a questionnaire to measure all variables. Research in Bulak tourism industry Depok City is interesting because the location is attached to the tourist village, with the potential of products and marketing reaching nationally, as well as because of the presence of many large traders from the national market ordering both online and coming to pick up merchandise on a national and regional marketing scale. The focus in this study is 90 garment businesses in Bulak tourism industry, where every entrepreneur has workers, production machinery, and marketing systems, so we can analyze digital literacy and economic literacy, as well as entrepreneurial skills.

This research was carried out from March to September 2020, with descriptive data collection and research orientation, because it was constrained by COVID-19. The population in this study is 90 entrepreneurs of small- and medium-sized enterprises selected via saturated sampling. Data analysis was performed quantitatively and descriptively using SPSS version 25.0 software. Based on the validity test critical value table, each test item is to be valid when at significance level of 0.05 obtained $t$ value count $\geq t$ table, and reliability test questionnaire items obtained the number of valid and reliable questionnaire items, seven for digital literacy variable, nine for economic literacy, six for job skills, and 12 questionnaire items for performance of SME entrepreneurs. Then, following the collection of research data, testing normality, regression, and analysis path test to know the direct and indirect influence between variables were undertaken (Riduwan \& Engkos, 2011).

\section{Results and Discussion}

Based on the data obtained through the process of filling out questionnaires by 90 respondents, the performance variable of SME entrepreneurs, from a set of 15 items, 12 items were identified as valid. For digital literacy, from a set of eight items, seven items were identified as valid. For economic literacy, from a set of 11 items, nine items were identified as valid. For entrepreneurial skills, six items were identified as valid. Variables are valid above 0.05 (ValidityCorrected Item-Total Correlation) and Reliability Cronbach's Alpha of $0.771,0.790,0.783$, and 0.759 , respectively. The total score of each variable as data input and discussion is shown in Table 1.

The research then carried out test requirements that aim to find out whether the data is distributed normally or not, and test linearity. Based on statistical tests conducted with SPSS 25 , then Variable $\mathrm{X} 1$ is digital literacy and variable $\mathrm{X} 2$ is economic literacy, X3 is entrepreneurial skill, while variable $\mathrm{X} 4$ is the performance of SMEs. Based on the normality test, digital literacy variables, economic literacy, entrepreneurial skills, and performance of SME entrepreneurs showed a p-value of $0.200,0.187,0.138$, and 0.153 , respectively. These results show a greater value when compared to the level of significance greater than 0.05 , so that it meets normally distributed data requirements. Thus, the data normality requirements are met for all the variables studied. Further linearity and path coefficient tests are carried out.

The analysis process begins with the affirmation of the analytical frame of thought (constellation) based on the structure of the influence pathways built in the study, namely, the model structure in Figure 2.1 is further analyzed based on sub-structures $\left(X_{1}, X 2\right.$, and $X_{3}$ to $\left.X_{4}\right)$ sub-structures $\left(X_{1}\right.$ and $\mathrm{X}_{2}$ to $\left.\mathrm{X}_{3}\right)$, and sub-structure/correlation $\left(\mathrm{X}_{1}\right.$ to $\left.\mathrm{X}_{2}\right)$. Based on the calculation, results obtained matric correlation coefficient between variables that are the basis of the analysis. The basis of the matrix calculation above can be used as a guideline to develop an analysis of the path between variables by calculating the inverse value of the correlation matrix.

By using SPSS 25.00, the results outlined between structures with the development of sub-structure model equation models $1\left(\mathrm{X}_{1}\right.$ and $\mathrm{X}_{2}$ to $\left.\mathrm{X}_{3}\right)$, digital literacy (X1), and economic Literacy (X2) contribute simultaneously to entrepreneurial skills (X3). Model structure: X3 $=\rho \times 3 \times 1$ X1 $+\rho \times 3 \times 1 X 2+\rho \times 3 \varepsilon$. The overall test of digital literacy (X1) and economic literacy (X2) contributes simultaneously to entrepreneurial skills (X3) shown on Table 2.

Based on individual data testing [(X1 related to $\mathrm{X} 3)$ and (X2 related to X3)], digital literacy (X1) and economic literacy (X2) contribute simultaneously to entrepreneurial skills (X3). Based on the model, the summary obtained the value $R$ square $=0.413$, and the Anova table gets a value $F$ of 30,558 with a probability value $(\mathrm{sig})=0.000$. Because of the value of sig $<0.05$, then there is a significant influence. Therefore, individual data testing has been carried out and it meets the path analysis data requirements (Riduwan \& Engkos K, 2011); the result of the path coefficient is px3x 1 $=0.317$. It appears that in the Sig (significant) column in the coefficients table, a sig value of 0.09 is obtained. It turns out that the sig value of 0.009 is smaller than the probability value of 0.05 or the value of $0.05>0.009$, meaning the coefficient of the path analysis is significant. So, digital literacy (X1) contributes significantly to entrepreneurial skills (X3). 
Table 1: SME Entrepreneur Research Variable Score Data

\begin{tabular}{|c|c|c|c|c|c|}
\hline Indicator & & Question Item & Score & $\begin{array}{l}\text { Total } \\
\text { score }\end{array}$ & Percentage \\
\hline \multicolumn{6}{|c|}{ Performance of SME Entrepreneurs } \\
\hline \multirow{3}{*}{ Increased Production } & EP1 & $\begin{array}{l}\text { There has been an increase in acceptance of my } \\
\text { business in the last } 3 \text { years }\end{array}$ & \multirow{3}{*}{947} & \multirow{12}{*}{3777} & \multirow{3}{*}{25,1} \\
\hline & EP2 & $\begin{array}{l}\text { My business is experiencing increased production } \\
\text { capacity }\end{array}$ & & & \\
\hline & EP3 & $\begin{array}{l}\text { My business is experiencing an increase in sales } \\
\text { volume }\end{array}$ & & & \\
\hline \multirow{5}{*}{$\begin{array}{l}\text { Business Unit } \\
\text { Development }\end{array}$} & EP5 & I'm adding a new business unit & \multirow{5}{*}{1584} & & \multirow{5}{*}{41,9} \\
\hline & EP6 & $\begin{array}{l}\text { I was able to achieve the target amount and quality of } \\
\text { production }\end{array}$ & & & \\
\hline & EP7 & My business has new product innovations & & & \\
\hline & EP8 & Customers with good loyalty increase & & & \\
\hline & EP9 & $\begin{array}{l}\text { My business production capacity can meet consumer } \\
\text { demand with inventory }\end{array}$ & & & \\
\hline \multirow{2}{*}{$\begin{array}{l}\text { Increase in Sales } \\
\text { Amount }\end{array}$} & EP12 & I provide after-sales service for customer satisfaction & \multirow{4}{*}{1246} & & \multirow{4}{*}{33} \\
\hline & EP13 & Many new customers are buying my products & & & \\
\hline \multirow{2}{*}{ Business Profit earned } & EP14 & The annual sales target I set was reached & & & \\
\hline & EP15 & My business has increased operating profit & & & \\
\hline \multicolumn{6}{|l|}{ Digital Literacy } \\
\hline Access & DL1 & $\begin{array}{l}\text { I was able to access the online store in developing my } \\
\text { business }\end{array}$ & 315 & \multirow{7}{*}{2224} & 14,2 \\
\hline Manage & DL2 & I updated my sales information online & 321 & & 14,4 \\
\hline Integrate & DL3 & I can use some online media for business purposes & 317 & & 14,3 \\
\hline $\begin{array}{l}\text { Analyzing and } \\
\text { Evaluating Information }\end{array}$ & DL4 & I can choose accurate information from online media & 311 & & 14 \\
\hline $\begin{array}{l}\text { Building new } \\
\text { Knowledge }\end{array}$ & DL6 & Online digital facilities provide new knowledge for me & 320 & & 14,4 \\
\hline \multirow{2}{*}{$\begin{array}{l}\text { Create and } \\
\text { communicate with } \\
\text { people }\end{array}$} & DL7 & Online media makes my business network grow & 320 & & \multirow{2}{*}{14,4} \\
\hline & DL8 & Lots of new relationships in my online business & 320 & & \\
\hline \multicolumn{6}{|l|}{ Skills of SMEs } \\
\hline Technical Skills & ES1 & $\begin{array}{l}\text { I can operate any equipment used in working } \\
\text { technically }\end{array}$ & 311 & \multirow{6}{*}{2198} & 14,2 \\
\hline Management Skills & ES2 & I was able to manage the effort to run properly & 314 & & 14,3 \\
\hline \multirow{2}{*}{ Entrepreneurial skills } & ES3 & I can overcome any business risks that may arise & \multirow{2}{*}{617} & & 28 \\
\hline & ES4 & I'm making innovations from existing businesses & & & $\angle 0,1$ \\
\hline \multirow{2}{*}{$\begin{array}{l}\text { Personality Maturity } \\
\text { Skills }\end{array}$} & ES5 & I can build good cooperation with other employees & 633 & & 28,8 \\
\hline & ES6 & $\begin{array}{l}\text { I can establish good communication with other } \\
\text { employees in this company }\end{array}$ & 323 & & 14,7 \\
\hline
\end{tabular}


Table 1: (Continued)

\begin{tabular}{|c|c|c|c|c|c|}
\hline \multicolumn{6}{|l|}{ Economic Literacy } \\
\hline & EL1 & Analyze changes in demand for goods & 327 & \multirow{9}{*}{2865} & 11,4 \\
\hline \multirow{8}{*}{$\begin{array}{l}\text { Developed Economic } \\
\text { Literacy for SMEs from }\end{array}$} & EL2 & Able to manage entrepreneurial roles & 321 & & 11,2 \\
\hline & EL4 & Analyze changes in supply and demand & 327 & & 11,4 \\
\hline & EL5 & Analyze the impact of government policy & 321 & & 11,2 \\
\hline & EL6 & Analyze the impact of changes in demand and supply & 317 & & 11,1 \\
\hline & EL7 & Explain the limited use of resources & 304 & & 10,6 \\
\hline & EL8 & $\begin{array}{l}\text { Analyze the costs and benefits of economic } \\
\text { transactions }\end{array}$ & 308 & & 10,8 \\
\hline & EL9 & Analyze the impact of inflation & 327 & & 11,4 \\
\hline & EL11 & Analyze industry development & 313 & & 10,9 \\
\hline
\end{tabular}

Table 2: Model Summary and Coefficients Research Data

\begin{tabular}{|c|c|c|c|c|c|}
\hline \multirow{2}{*}{ Model } & \multirow{2}{*}{$\frac{\text { Dependent Variable }}{\text { (Constant) }}$} & \multicolumn{2}{|c|}{ Independent Variables } & \multirow{2}{*}{$\mathbf{F}$} & \multirow{2}{*}{ R Square } \\
\hline & & Dig_Lit_X1 & Eco_Lit_X2 & & \\
\hline Coefficients & 9,011 & 0,217 & 0,203 & 30,558 & 0,413 \\
\hline SE & 1,534 & 0,081 & 0,064 & & \\
\hline Beta & & 0,317 & 0,375 & & \\
\hline t-test & 5,874 & 2,683 & 3,178 & & \\
\hline sig & 0,000 & 0,009 & 0,002 & & \\
\hline
\end{tabular}

The influence of economic literacy (X2) contributes to entrepreneurial skills (X3), the test is individually indicated by table coefficients, that the coefficient results path $\mathrm{p} \times 3 \times 2=0.375$. It is noticeable that in the Sig column (significant) in table coefficients, a sig value of 0.002 is obtained. It turns out that the sig value of 0.002 is smaller than the probability value of 0.05 or the value of $0.05>0.002$, meaning the coefficient of the path analysis is significant. economic literacy (X2) contributes significantly to entrepreneurial skills (X3). The empirical causal relationship framework between X1 and X2 related to $\mathrm{X} 3$ can be created through the Model 1 structure equation model: $\mathrm{X} 3=\rho \times 3 \mathrm{x} 1 \mathrm{X} 1+\rho \mathrm{x} 3 \mathrm{x} 1 \mathrm{X} 2+\rho \mathrm{x} 3 \varepsilon . \mathrm{X} 3$ $=0,295 \mathrm{X} 1+0,414 \mathrm{X} 2+0,61 \varepsilon$

The $\mathrm{R}$ value of $\mathrm{x} 3 . \mathrm{x} 1 . \mathrm{x} 2$ or $\mathrm{R}$ square can be seen in the model summary that is 0,413 . To find the value $\rho \times 3 \varepsilon$ (remaining variable) is determined with the formula: $\rho \times 3 \varepsilon 2$ $=1-\mathrm{R}^{2} \times 3 \times 1 \times 2=1-0.413=0.587$. Based on the formula of the contribution of the above track analysis, the variable digital literacy $(\mathrm{X} 1)$ and economic literacy $(\mathrm{X} 2)$ relate to entrepreneurial skills (X3).

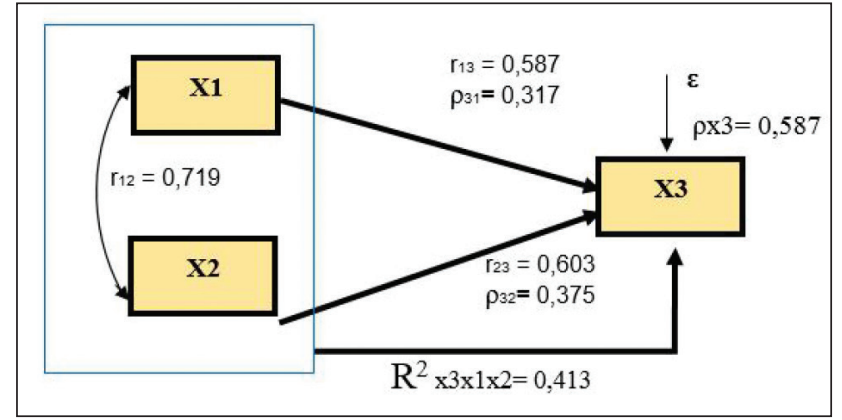

Figure 1: Empirical Causal Relationship Path Diagram X1 and X2 to X3

The path analysis shows that the form of the model is acceptable and gives the result of the contribution of each variable, as follows: digital literacy (X1) directly affects entrepreneurial skills (X3) by $0.317^{2}=0.10 \%$; economic literacy (X2) directly affects entrepreneurial skills (X3) by $0.375^{2}=0.140$ or $\left.14 \%, 3\right)$. Digital literacy (X1) and economic literacy (X2) simultaneously directly affect the entrepreneurial 
skills $(\mathrm{X} 3)$ of $\mathrm{R}^{2}$ square $=0.413=41.3 \%$. The remaining 0,587 or $58.7 \%$ was influenced by other factors that could not be explained in the study.

Sub-structure model equations $2\left(\mathrm{X}_{1}, \mathrm{X}_{2}\right.$, and $\mathrm{X}_{3}$ to $\left.\mathrm{X}_{4}\right)$ to determine the influence of digital literacy (X1), economic literacy (X2), and entrepreneurial skills (X3) contribute simultaneously to the performance of SME entrepreneurs (X4). Model structure: X4 $=\rho x 4 \times 1$. X1 $+\rho x 4 \times 2 . X 2+$ $\rho \times 4 \times 2$. X $3+\rho x 4 . \varepsilon 2$. Structure of influence pathways between research variables hypothesized in calculating the Model 2 path coefficient, the test is shown on Table 3.

In the table, the above model obtained the value $\mathrm{R}$ square $=0.889$ and gets a value of $\mathrm{F}$ of 258,711 with a probability value $(\mathrm{sig})=0.000$. Because of the value of $\mathrm{sig}<0.05$, it means there is a significant influence. Therefore, individual testing can be done. Individual test model 2: digital literacy (X1), economic literacy (X2), and entrepreneurial skills (X3) contribute simultaneously to the performance of SME entrepreneurs (X4).

The test individually indicate, that the result of the path coefficient is $\mathrm{px} 4 . \mathrm{x} 1=0.705$. It appears that, in the Sig (significant) column in the coefficients table, a sig value of 0.00 is less than the probability value of 0.05 or a value of $0.05>0.00$, meaning the coefficient of the path analysis is significant. So, digital literacy (X1) contributes significantly to the performance of SME entrepreneurs (X4). The influence of economic literacy (X2) contributes to the performance of SME entrepreneurs (X4), tests individually indicated the coefficient results of the path $\mathrm{px} 4 . \mathrm{x} 2=0.217$. It appears that the Sig (significant) column shows the sig value of 0.000 , is less than the probability value of 0.05 or a value of $0.05>0.009$, meaning the coefficient of the path analysis is significant. So, economic literacy (X2) contributes significantly to the performance of SME entrepreneurs (X4).

The influence of entrepreneurial skills (X3) contributes to the performance of SME entrepreneurs (X4); tests individually indicated the coefficient results of the path px4. $\mathrm{x} 2=0.114$, the coefficient is 0.012 , sig value is less than the probability value of 0.05 or the value of $0.05>0.012$, meaning the coefficient of the path analysis is significant. Entrepreneurial skills (X3) contributes significantly to the performance of SME entrepreneurs (X4). The empirical causal relationship framework between $\mathrm{X} 1, \mathrm{X} 2, \mathrm{X} 3$ to $\mathrm{X} 4$ can be created through the model structure equation as follows: $\mathrm{X} 4=\rho \mathrm{x} 4 \mathrm{x} 1 \mathrm{X} 1+\rho \mathrm{x} 4 \mathrm{x} 2 \mathrm{X} 2+\rho \mathrm{x} 4 \mathrm{x} 2 \mathrm{X} 3+\rho \mathrm{x} 4 \varepsilon 2 . \mathrm{X} 4=$ $0,705 \mathrm{X} 1+0,217 \mathrm{X} 2+0,114 \mathrm{X} 3+\rho \mathrm{x} 4 \varepsilon 2 . \mathrm{R}$ value $\mathrm{x} 4 \mathrm{x} 3 \mathrm{x} 1$. $\mathrm{x} 2$ or $\mathrm{R}$ square can be seen in the value $\mathrm{px} 4 \varepsilon 2$ (Remaining variable) is specified with the following formula $\rho \times 4 \varepsilon 2=$ $1-\mathrm{R}^{2}{ }_{\mathrm{x} 4 \times 1 \times 23 \times 1 \times 2}=1-0.889=0.111$.

The formulation of the contribution of the above path analysis can included the contribution of variable digital literacy (X1), economic literacy (X2), and entrepreneurial skills (X3), which contributing simultaneously to the performance of SME entrepreneurs (X4) as follows:

Table 3: Model Summary and coefficients research data

\begin{tabular}{|c|c|c|c|c|c|c|}
\hline \multirow{2}{*}{ Model } & \multirow{2}{*}{$\begin{array}{c}\text { Dependent } \\
\text { Variable (Constant) }\end{array}$} & \multicolumn{3}{|c|}{ Independent Variables } & \multirow{2}{*}{$\mathbf{F}$} & \multirow{2}{*}{ R Square } \\
\hline & & Digital Literacy & Economic Literacy & Entrepreneurial Skills & & \\
\hline Coefficients & 2,234 & 1,063 & 0,259 & 0,251 & 258,71 & 0,889 \\
\hline SE & 1,658 & 0,077 & 0,062 & 0,098 & & \\
\hline Beta & & 0,705 & 0,217 & 0,114 & & \\
\hline t-test & 1,348 & 13,827 & 4,194 & 2,559 & & \\
\hline $\operatorname{sig}$ & 0,181 & 0,000 & 0,000 & 0,012 & & \\
\hline
\end{tabular}

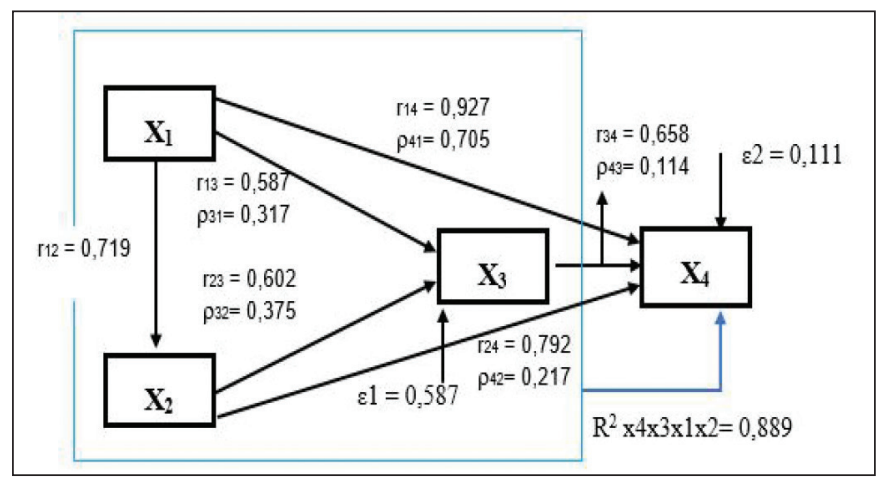

Figure 2: Empirical Causal Relationship Path Diagram X1, X2, and X3 to X4 
Table 4: Decomposition Summary of Coefficient of Models 1, and 2 Obtained Direct Influence, Indirect Influence and Total Influence Between Digital Literacy Variables (X1), Economic Literacy (X2), and Entrepreneurial Skills (X3) Contributes Simultaneously to The Performance of SME Entrepreneurs (X4)

\begin{tabular}{|c|c|c|c|c|}
\hline \multirow{2}{*}{ Variable Influence } & \multicolumn{2}{|c|}{ Causal influence I } & \multirow{2}{*}{ Remaining $\varepsilon 1$ and $\varepsilon 2$} & \multirow{2}{*}{ Total } \\
\hline & Direct & Indirect (Via X3) & & \\
\hline \multirow[t]{2}{*}{$\mathrm{X} 1$ to $\mathrm{X} 4$} & 0.705 & - & - & 0.705 \\
\hline & - & $0.705+(0.317 \times 0.114)$ & - & 0.741 \\
\hline \multirow[t]{2}{*}{$\mathrm{X} 2$ to $\mathrm{X} 4$} & 0.217 & - & - & 0.217 \\
\hline & - & $0.217+(0.375 \times 0.217)$ & - & 0.298 \\
\hline $\mathrm{X} 1 \times 2 \times 3$ to $\times 4$ & 0.587 & - & 0.111 & 1.000 \\
\hline $\mathrm{X} 1$ to $\mathrm{X} 3$ & 0.317 & - & - & 0.295 \\
\hline $\mathrm{X} 2$ to $\mathrm{X} 3$ & 0.375 & - & - & 0.414 \\
\hline $\mathrm{X} 1 \times 2$ to $\mathrm{X} 3$ & 0.413 & - & 0.587 & 1.000 \\
\hline
\end{tabular}

The path analysis shows that the form of the model is acceptable and gives the result of the contribution amount of each variable. The large direct and indirect influence (through $\mathrm{X} 3$ ) and total influence of digital literacy (X1), economic literacy (X2), and entrepreneurial skills (X3) contribute simultaneously to the performance of SME entrepreneurs (X4) as follows: direct effect of variable X1 on X4 $=0.705$; indirect influence between variable $\mathrm{X} 1$ to $\mathrm{X} 4$ through $\mathrm{X} 3=$ $0.705+(0.317741$. $\mathrm{x} 0.114)=0$; the total effect of $\mathrm{X} 1$ on $\mathrm{X} 4$ is $0,741.2$ ); direct effect of variable $\mathrm{X} 2$ on $\mathrm{X} 4=0.217$; indirect influence between variable X2 to X4 through X3 = $0.217+(0.375 \times 0.217)=0.298$; the total effect of $\mathrm{X} 2$ on the $\mathrm{X} 4$ is 0.298 .3 ). Digital literacy (X1) directly affects the performance of SME entrepreneurs $(\mathrm{X} 4)$ by $0.705^{2}=0.497$ or $49.7 \%$. 4); economic literacy contribution (X2) directly affects the performance of SME entrepreneurs (X4) by $0.217^{2}=0.047$ or $4.7 \%$

The contribution of digital literacy (X1), economic literacy (X2), and entrepreneurial skills (X3) contribute simultaneously to the performance of SME entrepreneurs (X4) of $\mathrm{R}^{2}=0.889=88.9 \%$. The remaining 0.111 or $11.1 \%$ was influenced by other factors that could not be explained in the study. Table 4 shows the decomposition summary of the line coefficient, direct influence, the total impact on this model is as follows:

The coefficient values points to the fact that all paths prove significant. Thus, the structural model proposed in this study does not need to be modified. This is because the path model that has been built on the evolving theory (research construct) has qualified for the testing of the statistical hypothesis.

Based on the data of the above research results, the relationship between variables can be descriptively posited. Data on the performance of entrepreneurs in SMEs is the primary data obtained through a Likert scale questionnaire with indicators of increase production, business unit development, increase in sales volume, and business profit earned. Twelve questionnaire items were answered by 90 respondents, with the highest score of 54 and the lowest score of 25 . The variance score is 48,257 , with a standard deviation of 6,947. The indicator with the highest score is: business growth of $41.90 \%$, with the addition of new business units and increased customer loyalty. While the lowest indicator is: increased production capacity with an increase in receipts in three years. This shows that SME entrepreneurs need to increase their production capacity and provide space for new business development for entrepreneurs.

Digital literacy data on SME entrepreneurship show the highest score of 32 and the lowest score of 14 . The variance score is 21,219 , with a standard deviation of 4,606 . The indicator with the highest score is: to build new knowledge and create, and communicate with people with a score of 320 or 14, 39\%. While the lowest indicator is: analyzing and evaluating information. This indicates that digital literacy in SMEs needs to improve in analyzing and evaluating information and entrepreneurs in SMEs are already building new knowledge, creating and communicating with people as a form of media utilization in shaping customers.

Economic literacy data on SME entrepreneurship identifies indicators able to analyze changes in demand for goods, able to manage the role of entrepreneurship, able to analyze changes in supply and demand, able to analyze the impact of government policy, able to analyze the impact of changes in demand and supply, able to explain the limited use of resources, able to analyze the costs and benefits of economic transactions, able to analyze the impact of inflation, able to analyze the development of the industry. The highest score is 43 and the lowest score is 13 . The variance score is 33,786 , with a standard deviation of 5,813 . The indicator with the highest score: can analyze the change in demand for goods, 
able to analyze changes in supply and demand, able to analyze the impact of inflation with a score of $11.41 \%$. While the lowest indicator is: can explain the limited use of resources. This indicates that to be able to explain the limited use of resources to SMEs, there needs to be an improvement in analyzing and being able to explain the limited use of resources.

Data of entrepreneurial skills on SME entrepreneurs with technical skills indicator, management skills, personality maturity skills. The highest score is 28 and the lowest score is 13 . The variance score is 9.916 , and a standard deviation of 3.149. The indicator with the highest score is: personality maturity skills with the ability to build good cooperation with other employees. While the lowest indicator is: technical skills with the ability to operate any equipment used in technical work. This indicates the need for development and training in technical skills in SME entrepreneurship.

\section{Conclusions}

The results of this research on the influence of digital literacy (X1), economic literacy (X2), and entrepreneurial skills (X3) on the performance of SMEs (X4) on entrepreneurship in Depok city can be summed up as follows: 1) there is a significant and positive influence of digital literacy on the performance of SME entrepreneurs, meaning that the higher the knowledge of digital literacy, the higher the performance of SME entrepreneurs; 2) there is a significant and positive influence of digital literacy on entrepreneurial skills, meaning that the higher the knowledge of digital literacy, the more entrepreneurial skills of SME entrepreneurs will increase; 3) there is a significant and positive influence of economic literacy on entrepreneurial skills, meaning the higher the knowledge of economic literacy, the entrepreneurial skills of SME entrepreneurs will increase; 4) there is a significant and positive influence of economic literacy on the performance of SME entrepreneurs, meaning the higher the knowledge of economic literacy, SME entrepreneur's performance will increase; 5) there is a significant positive influence of the entrepreneurial skills on the performance of SME entrepreneurs, meaning that the better the skills of entrepreneurs, the better the performance of SMEs.

Based on the research results, it shows that digital literacy has the greatest direct and indirect influence on the performance of SME entrepreneurs; this shows the importance of digital literacy in developing business and marketing networks. Performance development through entrepreneurial skills and literacy shows a positive and significant correlation. Management skills are able to contribute to performance. The ability of an entrepreneur in managing a business organization is also essential in achieving business success. Organizational ability and organizational learning affect financial performance
(Hindasah \& Nuryakin, 2020). Organizational skills as important management skills are learned to determine the performance of SMEs. Managerial abilities for entrepreneurs with their development strategies are important for company performance (Cheng et al., 2020).

The results of the research are the basis for suggestions that strengthen the argument of factors that influence the performance of SME entrepreneurs. This research can be used as a theoretical reference in developing the performance of SME entrepreneurs. It can be used by entrepreneurs especially on SMEs shopping tours to improve the performance of SMEs, such as SME office development, and material to optimize the role of SME entrepreneurs in shopping tourism to improve digital literacy education and training, economic literacy and entrepreneurial skills to improve the performance of SME entrepreneurs. For regional heads, the study results can be the basis for policymaking considerations to improve the performance of SME entrepreneurs.

\section{References}

Ambad, S. N. A., \& Damit, D. H. D. A. (2016). Determinants of Entrepreneurial Intention Among Undergraduate Students in Malaysia. Procedia Economics and Finance, 37(16), 108-114. https://doi.org/10.1016/s2212-5671(16)30100-9

Aujirapongpan, S., Ru-zhe, J., \& Jutidharabongse, J. (2020). Strategic Intuition Capability toward Performance of Entrepreneurs: Evidence from Thailand. Journal of Asian Finance, Economics and Business, 7(6), 465-473. https://doi. org/10.13106/jafeb.2020.vol7.no6.465

Ajzen, I. (2005), Attitudes, Personality and Behavior, (2nd edition), Berkshire, UK: Open University Press-McGraw Hill Education

Alvarez, S. A., \& Barney, J. A. Y. B. (2007). Discovery and Creation: Alternative Theories of Entrepreneurial Action. Strategic Entrepreneurship Journal, 1(November), 11-26. https://doi.org/10.1002/sej.4

Bourletidis, K., \& Triantafyllopoulos, Y. (2014). SMEs Survival in time of Crisis : Strategies, Tactics, and Commercial Success Stories. Procedia - Social and Behavioral Sciences, 148, 639-644. https://doi.org/10.1016/j.sbspro.2014.07.092

Bui, T. H. V., Nguyen, T. L. T., Tran, M. D., \& Nguyen, T. A. T. (2020). Determinants Influencing Entrepreneurial Intention among Undergraduates in Universities of Vietnam. Journal of Asian Finance, Economics and Business, 7(7), 369-378. https:// doi.org/10.13106/jafeb.2020.vol7.no7.369

Camba, A. L. (2020). Estimating the Nature of Relationship of Entrepreneurship and Business Confidence on Youth Unemployment in the Philippines. Journal of Asian Finance, Economics and Business, 7(8), 533-542. https://doi. org/10.13106/jafeb.2020.vol7.no8.533

Candra, N., \& Ashari, R. (2014). Technology Readiness and E-Commerce Adoption among Entrepreneurs of SMEs in 
Bandung City, Indonesia. Gadjah Mada International Journal of Business, 16(1), 69-88. https://journal.ugm.ac.id/gamaijb/ article/download/5468/4443

Cheng, T. Y., Li, Y., Lin, Y., \& Chih, H. (2020). Does the Fit of Managerial Ability with Firm Strategy Matters on Firm. Journal of Asian Finance, Economics and Business, 7(4), 9-19. https://doi.org/10.13106/jafeb.2020.vol7.no4.9

Egedy, T., Cerić, D., Dicka, J. N., \& et.al. (2018). Entrepreneurship as a potential driving force for the further development of rural areas - good examples from Visegrad countries Entrepreneurship as a potential driving force for the further development of rural areas. Studia Obszarów Wiejskich, 11(September), 103-127. http://dx.doi.org/10.7163/SOW.39.7

Fitriati, R., \& Hermiati, T. (2011). Entrepreneurial Skills and Characteristics Analysis on the Graduates of the Department of Administrative Sciences, FISIP University of Indonesia. Journal of Administrative and Bureaucratic Sciences, 17(3), 262-275. https://doi.org/10.20476/jbb.v17i3.788

Heinonen, J., \& Poikkijoki, S. A. (2006). An entrepreneurialdirected approach to entrepreneurship education: Mission impossible? Journal of Management Development, 25(1), 80-94. https://doi.org/10.1108/02621710610637981

Hindasah, L., \& Nuryakin, N. (2020). The Relationship between Organizational Capability, Organizational Learning and Financial Performance. Journal of Asian Finance, Economics and Business, 7(8), 625-633. https://doi.org/10.13106/ jafeb.2020.vol7.no8.625

Hunt, R. A., \& Kiefer, K. (2017). The entrepreneurship industry: Influences of the goods and services marketed to entrepreneurs. Journal of Small Business Management, 55(February), 231255. https://doi.org/10.1111/jsbm.12329

Iqomudin, M. A. (2017). The influence of Economic Literacy, Economic Education in families, and socio-economic background of parents on consumer decision-making on students of IPS Education State Islamic University Maulana Malik Ibrahim Malang. Thesis.

Kuckertz, A., Br, L., Gaudig, A., Hinderer, S., Reyes, A. M., Prochotta, A., Steinbrink, K. M., \& Berger, E. S. C. (2020). Startups in times of crisis - A rapid response to the COVID-19 pandemic. Journal of Business Venturing Insights, 13(April). https://doi.org/https://doi.org/10.1016/j.jbvi.2020.e00169

Lankshear, C. \& Knobel, M. (2015). Digital Literacy and Digital Literacies: - Policy, Pedagogy and Research Considerations for Education. Nordic Journal of Digital Literacy, 10, 8-20. DOI: 10.18261/issn.1891-943X

Looy, A. Van, \& Shafagatova, A. (2016). Business process performance measurement: a structured literature review of indicators, measures, and metrics. SpringerPlus, 5(1797), 1-24. https://doi.org/10.1186/s40064-016-3498-1

Lu, H., \& Wang, J. (2018). Entrepreneurial Intention of Two Patterns of Planned Behaviour and Alertness : Empirical Evidence in China. Journal of Asian Finance, Economics and Business, 5(2), 63-72. https://doi.org/10.13106/jafeb.2018.vol5.no2.63
Lusardi, A., \& Mitchell, O. S. (2007). Baby Boomer retirement security: The roles of planning, financial literacy, and housing wealth. Journal of Monetary Economics, 54(1), 205-224. https://doi.org/10.1016/j.jmoneco.2006.12.001

Maritz, A., Perenyi, A., Waal, G. De, \& Buck, C. (2020). Entrepreneurship as the Unsung Hero during the Current COVID-19 Economic Crisis: Australian Perspectives. Sustainability, 12(4612), 1-9. https://doi.org/doi:10.3390/ su12114612

Nadeem, A., Abedin, B., Cerpa, N., \& Chew, E. (2018). Editorial : Digital Transformation \& Digital Business Strategy in Electronic Commerce - The Role of Organizational Capabilities. Journal of Theoretical and Applied Electronic Commerce Research, 13(2), 1-8. https://doi.org/10.4067/S0718-18762018000200101

Nurjanah, S., Suparno, Kardoyo, \& Disman. (2020). The Effect of Economic Literacy, Capital, Labor, and Marketing on Development of Small And Medium Enterprises ( SMEs ). Journal of Entrepreneurship Education, 23(4), 1-11. https:// www.abacademies.org/articles/The-effect-of-economicliteracy-capital-labor-1528-2651-23-4-604.pdf

Quatraro, F., \& Vivarelli, M. (2013). Drivers of Entrepreneurship and Post-Entry Performance of Newborn Firms in Developing Countries (No. 7436). https://www.econstor.eu/ bitstream/10419/80699/1/749783508.pdf

Raposo, M., \& do Paço, A. (2011). Entrepreneurship education: the relationship between education and entrepreneurial activity. Psicothema, 23(3), 453-457.

Reis, J., Amorim, M., Melao, N., \& Patrícia, M. (2018). Digital Transformation: A Literature Review and Guidelines for Future Digital Transformation: A Literature Review and Guidelines for Future Research. World CIST, May. https://doi. org/10.1007/978-3-319-77703-0

Riduwan., \& Kuncoro, E.A. (2011). How to Use and Interpret Path Analysis. Bandung, Indonesia: CV Alfabeta

Saptono, A., Wibowo, A., \& Shandy, B. (2020). Factors Influencing Intention to Establish Business ( Start-up) Students' a Digital. 12(8), 73-91.

Satalkina, L. (2020). Digital Entrepreneurship and its Role in Innovation Systems: A Systematic Literature Review as a Basis for Future Research Avenues for Sustainable Transitions. Sustainability Review, 12(2764), 1-27. https://doi.org/ doi:10.3390/su12072764

Savrul, M. (2017). The Impact of Entrepreneurship on Economic Growth: GEM Data Analysis. Journal of Management, Marketing, and Logistics (JMML), 4(3), 320-326. https://doi. org/http://doi.org/10.17261/Pressacademia.2017.494

Sebikari, K. V. (2014). Entrepreneurial Performance and Small Business Enterprises in Uganda. International Journal of Small Business and Entrepreneurship Research, 2(4), 1-12. http:// www.eajournals.org/wp-content/uploads/EntrepreneurialPerformance-and-Small-Business-Enterprises-in-Uganda1.pdf

Sharma, S. (2016). The relation between education and employment outcomes in the Indian labor market: A critical review of the 
literature. International Journal of Research in Economics and Social Sciences, 6(4), 43-55.

Suparno, \& Saptono, A. (2018). Entrepreneurship education and its influence on financial literacy and entrepreneurship skills in college. Journal of Entrepreneurship Education, 21(4), 1-11.

Suparno, Wibowo, A., Herlitah, Mukhtar, S., Kusumojanto, D. D., Suwatno, Narmaditya, B. S., \& Raudah, M. (2019). Do entrepreneurial education and training impact on entrepreneurial skills-based ecopreneurship? Humanities and Social Sciences Letters, 7(4), 246-253. https://doi.org/10.18488/ journal.73.2019.74.246.253

Suparno, Wibowo, A., Mukhtar, S., Narmaditya, B. S., \& Sinta, H. D. (2019). The Determinant Factors of Development Batik Cluster Business: Lesson From Pekalongan, Indonesia. Journal of Asian Finance, Economics and Business, 6(4), 227233. https://doi.org/10.13106/jafeb.2019.vol6.no4.227

Tayibnapis, A. Z., Wuryaningsih, L. E., \& Gora, R. (2018). The Development of Digital Economy in Indonesia 1. International Journal of Management \& Business Studies, 8(3), 14-18. http:// www.ijmbs.com/Vol8/issue3/2-ahmad-zafrullah-tayibnapis.pdf
Valliere, D., \& Peterson, R. (2009). Entrepreneurship and economic growth: Evidence from emerging and developed countries. Entrepreneurship \& Regional Development, 21(5), 459-480. https://doi.org/http://dx.doi.org/10.1080/08985620802332723

Van Gelderen, M., Brand, M., Van Praag, M., Bodewes, W., Poutsma, E., \& Van Gils, A. (2008). Explaining entrepreneurial intentions by means of the theory of planned behavior. Career Development International, 13(6), 538-559. https://doi. org/10.1108/13620430810901688

Wardana, L. W., Handayati, P., Narmaditya, B. S., \& Wibowo, A. (2020). Determinant Factors of Young People in Preparing for Entrepreneurship : Lesson from Indonesia. Journal of Asian Finance, Economics and Business, 7(8), 555-565. https://doi. org/10.13106/jafeb.2020.vol7.no8.555

Wu, Y. J. (2019). Entrepreneurship through the platform strategy in the digital era: Insights and research opportunities Entrepreneurship through the platform strategy in the digital era: insights and research opportunities. Computers in Human Behavior, 95, 315-323. https://doi.org/10.1016/j. chb.2018.03.033 